http://dx.doi.org/10.11646/phytotaxa.167.2.3

\title{
Seed morphology of bladderworts: a survey on Utricularia sect. Foliosa and sect. Psyllosperma (Lentibulariaceae) with taxonomic implications
}

\author{
CRISTINE GOBBO MENEZES ${ }^{1 *}$, EDUARDO CUSTÓDIO GASPARINO ${ }^{1}$, PAULO CESAR BALEEIRO² \& \\ VITOR FERNANDES OLIVEIRA DE MIRANDA ${ }^{1}$ \\ ${ }^{I}$ Faculdade de Ciências Agrárias e Veterinárias, UNESP - Univ Estadual Paulista, Campus Jaboticabal, Departamento de Biologia \\ Aplicada à Agropecuária, Laboratório de Sistemática Vegetal e Palinologia, Via de Acesso Prof. Paulo Donato Castellane s/n, CEP \\ 14884-900, Jaboticabal,SP, Brazil; e-mail: cristine.menezes@gmail.com \\ ${ }^{2}$ Laboratório de Sistemática Vegetal, Departamento de Botânica, Instituto de Biociências, edificio sobre as ondas, Universidade de \\ São Paulo, Rua do Matão 277, Cidade Universitária, CEP 05508-900, São Paulo, SP, Brazil. \\ *Author for correspondence
}

\begin{abstract}
Species from Utricularia sect. Foliosa and sect. Psyllosperma were studied based on seed characteristics. Our goals were to search for informative characters useful to species delimitations, especially for very polymorphic species such as $U$. amethystina, and also to provide an identification key and discussion about the delimitation of both sections. The qualitative characters of seeds were more useful than quantitative ones for taxonomic purposes but, as presented here in an identification key, it was impossible to distinguish three species from each other (Utricularia huntii, U. praelonga and U. tridentata). Our results are not enough for deep speculations about the delimitation of both sections. However, they do not agree with Taylor's system, because it was impossible to separate the studied species in two clearly different groups. However, the variability found in the seed characters was evaluated in this work and we also briefly discussed the ecologic implications of some seed traits.
\end{abstract}

Key words: dispersion, exalbuminous seeds, morphometry, taxonomy, testa, Utricularia amethystina

\section{Introduction}

Lentibulariaceae Richard in Poiteau \& Turpin (1808: 23) is a carnivorous plant family whose species usually show diminutive anatropous seeds (Farooq 1964, Shivaramiah 1967, Rajan and Kumar 1973, Corner 1976). Interestingly some lineages within the family lost the cotyledons (Kondo et al. 1978, Płachno \& Świątek 2009), particularly Genlisea Saint-Hilaire (1833: 428) and some species of Utricularia Linnaeus (1753: 18), which represents an apomorphic status considering that in the early branching genus Pinguicula Linnaeus (1753: 17) (Jobson et al. 2003, Müller et al. 2004) the cotyledons are present, even if often reduced from two to just one (Degtjareva et al. 2004). The embryonic traits in Pinguicula are relevant to delimitate infrageneric taxa (Degtjareva et al. 2004). Characters from Genlisea seeds are also important for infrageneric delimitation: Genlisea subgen. Genlisea, with pyramidal seeds, and subgen. Tayloria (Fromm 1977: 2) Fischer et al. (2000: 293), with prismatic, globose or ellipsoidal seeds (Fromm-Trinta 1979, Fleishmann et al. 2011, 2012, Fischer et al. 2000).

Utricularia is the richest and most widespread genus in the family, which also reflects the high morphological diversity of the traps (Taylor 1989, Guisande et al. 2007, Reifenrath et al. 2006). Different lineages within the genus spread out and adapted to different environments, as the aquatic (free-floating or affixed forms) and terrestrial habitats, assuming also the lithophytic, epiphytic and reophytic forms. As for the traps, seeds of Utricularia are also very morphologically variable, especially concerning the form and tegument surface (testa), as noticed and described by different authors (e.g. Abraham \& Subramanyan 1965, Taylor 1989). Therefore, if the seeds are as variable as the traps in morphologic traits, also should be useful for the taxonomy within the genus. 
1. Ovate-deltoid seeds; star-shaped testa cells U. calycifida

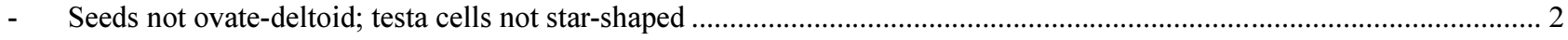

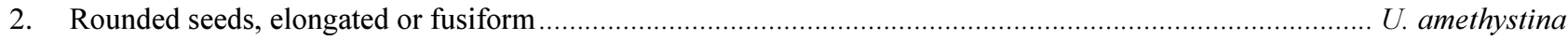

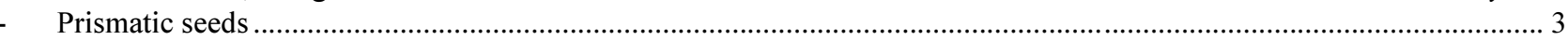

3. Periclinal walls of testa cells with tuberculous surface .................................................................... U. hispida

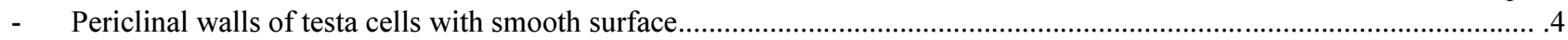

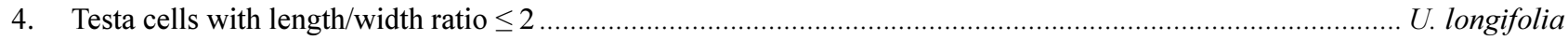

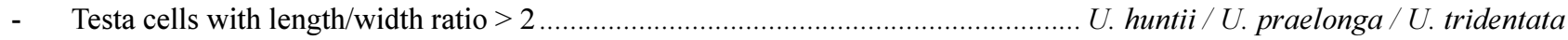

\section{Acknowledgements}

We want to sincerely thank Laboratório de Microscopia Eletrônica (Unesp/FCAV) for all logistical support to SEM analyses, and especially technician Claudia Aparecida Rodrigues for her precious and kind assistance for sample and photo preparation, and also to herbaria HB, INPA, IPA, SPF and UB for loaning the samples. Special thanks to Yoannis Domínguez Rodríguez, Saura Rodrigues da Silva and Luiz Eduardo Mascaro for all the fruitful discussion in our laboratory group. This paper is part of the first author's PhD project supported by Coordenação de Aperfeiçoamento de Pessoal de Nível Superior (Capes) and Conselho Nacional de Desenvolvimento Científico e Tecnológico (CNPq grants N. 14884/2012-6), and Unesp/PROPe, Univ Estadual Paulista, Brazil. The samples were collected with the SisBio authorization n. 26938-1 by the Ministério do Meio Ambiente (MMA) and Instituto Chico Mendes de Conservação da Biodiversidade (ICMBio).

\section{References}

Abraham, V. \& Subramnyanm, K. (1965) Studies on seeds of various taxa of Utricularia occurring in west Bengal. Botanical Survey of India, 62: 97-102.

Benjamin, L. 1847. Lentibularieae. Linnaea, 20: 485-498.

Corner, E.J.H. (1976) Lentibulariaceae. In: Corner, E.J.H. (ed.) The Seeds of Dicotyledons. Cambridge University Press, Cambridge, pp. 173-174.

Conti, F. \& Peruzzi, L. (2006) Pinguicula (Lentibulariaceae) in central Italy: taxonomic study. Annales Botanici Fennici 43: 321-337.

Degtjareva, G., Casper, J., Hellwig, F. \& Sokoloff, D. (2004) Seed morphology in the genus Pinguicula (Lentibulariaceae) and its relation to taxonomy and phylogeny. Botanische Jahrbücher 125: 431-452. http://dx.doi.org/10.1127/0006-8152/2004/0125-0431

Eriksson, O. \& Kainulainen, K. (2011) The evolutionary ecology of dust seeds. Perspectives in Plant Ecology, Evolution and Systematics 13: 73-87. DOI: http://dx.doi.org/10.1016/j.ppees.2011.02.002

Farooq, M. (1964) Studies in Lentibulariaceae - Embriology of Utricularia stellaris Linn.f. var. inflexuosa. Part 1. Flower, organogeny, ovary, megasporogenesis and female gametophyte. Proceedings of the National Academy of Sciences of the India 30: 263-279.

Fernández-Pérez, A. (1964) Plantas Insetivoras I. Lentibulariaceas de Colombia y Peru. Caldasia 9(41): 5-84.

Fischer E., Porembski S. \& Barthlott W. (2000) Revision of the genus Genlisea (Lentibulariaceae) in Africa and Madagascar with notes on ecology and phytogeography. Nordic Journal Botany 20: 291-318. http://dx.doi.org/10.1111/j.1756-1051.2000.tb00746.x

Fleischmann, A., Rivadavia, F., Gonella, P.M. \& Heubl, G. (2011) A revision of Genlisea subgenus Tayloria (Lentibulariaceae). Phytotaxa 433: 1-40.

Fleischmann, A. (2012) A Monograph of the Genus 'Genlisea'. Redfern Natural History Productions, Ltd., Poole. 727 pp.

Fromm-Trinta, E. (1977) Tayloria Fromm-Trinta-Nova Seção do gênero Genlisea St.-Hil. (Lentibulariaceae). Boletim do Museu Nacional Rio de Janeiro, Botanica 44: 1-4.

Fromm-Trinta, E. (1979) Revisão das espécies do gênero Genlisea St.-Hil. (Lentibulariaceae) das regiões sudeste e sul do Brasil. Rodriguésia 31: 17-139.

Gardner, G. (1842) Contributions towards a Flora of Brazil. London Journal of Botany 1: 528-545.

Guisande, C., Granado-Lorencio, C., Andrade-Sossa, C. \& Duque, S.R. (2007) Bladderworts. Functional Plant Science and Biotechnology 1: 58-68.

Jobson, R.W., Playford, J., Cameron, K.M. \& Albert, V.A. (2003) Molecular phylogenetics of Lentibulariaceae inferred from plastid rps 16 intron and trnL-F DNA sequences: implications for character evolution and biogeography. Systematic 
Botany 28: 157-171.

Kamiénski, F. (1891) Lentibulariaceae. In: Engler, A. \& Prantl, K.A.E, Die Naturalichen Pflanzenfamilien. W. Engelmann, IV, 3b, (preprint), Leipzig, 108-123.

Kondo, K., Segawa, M. \& Nehira, K. (1978) Anatomical Studies on Seeds and Seedlings of Some Utricularia (Lentibulariaceae). Brittonia 30: 89-95.

http://dx.doi.org/10.2307/2806465

Lamarck, J.B.A.P. de M. (1791) Tableau encyclopedique et methodique des trois règnes de la nature: Botanique 1. Panckoucke, Paris, $250 \mathrm{pp}$. http://dx.doi.org/10.5962/bhl.title.218

Linnaeus, C. (1753) Species Plantarum 1. Imprensis Laurentii Salvii, Holmiae, 560 pp.

Miranda, V.F.O. de \& Rivadavia, F. (2010) Lentibulariaceae. In: Forzza, R.C., Baumgratz, J.F.A., Bicudo, C.E.M., Jr., A.A.C., Costa, A., Costa, D.P., Hopkins, M., Leitman, P.M., Lohmann, L.G., Maia, L.C., Martinelli, G., Menezes, M., Morim, M.P., Coelho, M.A.N., Peixoto, A.L., Pirani, J.R., Prado, J., Queiroz, L.P., Souza, V.C., Stehmann, J.R., Sylvestre, L.S., Walter, B.M.T. \& Zappi, D. (eds.) Catálogo de Plantas e Fungos do Brasil 2(1). Instituto de Pesquisas Jardim Botânico do Rio de Janeiro, Rio de Janeiro, pp. 1163-1166.

Miranda, V.F.O. de \& Rivadavia, F. (2013) Lista de Espécies da Flora do Brasil: Lentibulariaceae. Instituto de Pesquisas Jardim Botânico do Rio de Janeiro, Rio de Janeiro. Available from: http://floradobrasil.jbrj.gov.br/jabot/floradobrasil/FB146 (accessed: 10 June 2013).

Müller, K., Borsch, T., Legendre, L., Porembski, S., Theisen, I. \& Barthlott, W. (2004) Evolution of carnivory in Lentibulariaceae and the Lamiales. Plant Biology 6: 1-14. http://dx.doi.org/10.1055/s-2004-817909

Müller, K. \& Borsch, T. (2005) Phylogenetics of Utricularia (Lentibulariaceae) and molecular evolution of the trnK intron in a lineage with high substitutional rates. Plant Systematics and Evolution 250: 39-67. http://dx.doi.org/10.1007/s00606-004-0224-1

Płachno, B. \& Świątek, P. (2009) Unusual embryo structure in viviparous Utricularia nelumbifolia, with remarks on embryo evolution in genus Utricularia. Protoplasma 239: 69-80. http://dx.doi.org/10.1007/s00709-009-0084-1

Rajan, S.S. \& Kumar, D.J. (1973) Embryological studies in Lentibulariaceae. I. Floral morphology and embryology of Utricularia smithiana. Proceedings of the National Academy of Sciences 80: 18-25.

Reifenrath, K., Theisen, I., Schnitzler, J., Porembski, S. \& Barthlott, W. (2006) Trap architecture in carnivorous Utricularia (Lentibulariaceae). Flora 201: 597-605. http://dx.doi.org/10.1016/j.flora.2005.12.004

Richard, L.C.M. (1808) Lentibulariae. In: Poiteau, P.A. \& Turpin, P.J.F. Flore parisienne: contenant la description des plantes qui croissent naturellement aux environs de Paris 1. PR, Paris, pp. 26.

Saint-Hilaire, A.F.C. de. (1833) Voyage dans le District des Diamans du Brésil. Librairie-Gide, Paris, 454 pp.

Saint-Hilaire, A. \& Girard, F. de. (1838) Monographie des Primulacées et des Lentibularieés du Brésil méridional. Comptes Rendus Hebdomadaires des Séances de l'Académie des Sciences 7: 868-870.

Shivaramiah, G. (1967) Observations on the floral morphology and embriology of Utricularia stricticaulis Stapf. Proceedings of the National Academy of Sciences 65: 56-62.

Sylvén, N.O.V. (1909) Die Genliseen und Utricularien des Regnellschen Herbariums. Arkiv für Botanik 8: 1-48 pp.

Taylor, P. (1986) New Taxa in Utricularia (Lentibulariaceae). Kew Bulletin 41: 8-9.

Taylor, P. (1989) The Genus Utricularia — a taxonomic monograph. Kew Bulletin Additional Series 14: 724 pp.

Zamudio, S. \& Olvera, M. (2009) A new species of Utricularia (Lentibulariaceae) from Guerrero, Mexico. Brittonia 61: 119-125. http://dx.doi.org/10.1007/s12228-008-9063-7. 